\title{
Body composition of children with moderate and severe undernutrition and after treatment: a narrative review
}

\author{
Jonathan C. K. Wells
}

\begin{abstract}
Background: Until recently, undernourished children were usually assessed using simple anthropometric measurements, which provide global assessments of nutritional status. There is increasing interest in obtaining more direct data on body composition to assess the effects of undernutrition on fat-free mass (FFM) and its constituents, such as muscle and organs, and on fat mass (FM) and its regional distribution.

Main text: Recent studies show that severe-acute undernutrition, categorised as 'wasting', is associated with major deficits in both FFM and FM that may persist in the long-term. Fat distribution appears more central, but this is more associated with the loss of peripheral fat than with the elevation of central fat. Chronic undernutrition, categorised as 'stunting', is associated with deficits in FFM and in specific components, such as organ size. However, the magnitude of these deficits is reduced, or - in some cases - disappears, after adjustment for height. This suggests that FFM is largely reduced in proportion to linear growth. Stunted children vary in their FM - in some cases remaining thin throughout childhood, but in other cases developing higher levels of FM. The causes of this heterogeneity remain unclear. Several different pathways may underlie longitudinal associations between early stunting and later body composition. Importantly, recent studies suggest that short children are not at risk of excess fat deposition in the short term when given nutritional supplementation.
\end{abstract}

Conclusion: The short- and long-term functional significance of FFM and FM for survival, physical capacity and noncommunicable disease risk means that both tissues merit further attention in research on child undernutrition.

Keywords: Child undernutrition, Undernutrition, Body composition, Wasting, Stunting

\section{Background}

Despite substantial progress in prevention and treatment, child undernutrition remains a major global health challenge and still contributes to around half of all deaths in children under 5 years of age [1]. Greater understanding of how undernutrition affects different body components might enable the development of clinical and public health interventions that are more effective in promoting survival and long-term quality of life, through reversing tissue deficits and their functional consequences.

Until recently, undernourished children were usually assessed using simple anthropometric measurements,

\section{Correspondence: jonathan.wells@ucl.ac.uk}

Childhood Nutrition Research Centre, Population, Policy and Practice

Research and Teaching Department, University College London (UCL) Great

Ormond Street Institute of Child Health, 30 Guilford Street, London WC1N 1EH, UK

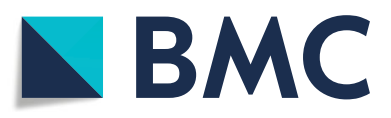

which provided global assessments of nutritional status. This approach built on conceptual advances made in the 1970s, when the pioneering nutritionist John Waterlow proposed a distinction between 'chronically' and 'acutely' undernourished children, based on measurements of height or weight [2]. Subsequently, this evolved into the routine practice of categorising children as either 'stunted' (defined as having an inadequate height for age z-score, HAZ), or 'wasted' (defined as having an inadequate weight for height $\mathrm{z}$-score, WHZ, or mid-upper arm circumference, MUAC). This approach can be further adapted to differentiate between moderate underweight-for-height, versus severe underweight-forheight, or wasting [3].

The nutrition research and practice community has widely adopted these practices and numerous reports now quantify the prevalence of wasted and stunted

(C) The Author(s). 2019 Open Access This article is distributed under the terms of the Creative Commons Attribution 4.0 International License (http://creativecommons.org/licenses/by/4.0/), which permits unrestricted use, distribution, and reproduction in any medium, provided you give appropriate credit to the original author(s) and the source, provide a link to the Creative Commons license, and indicate if changes were made. The Creative Commons Public Domain Dedication waiver (http://creativecommons.org/publicdomain/zero/1.0/) applies to the data made available in this article, unless otherwise stated. 
children [1]. There is growing recognition that such a dichotomous approach is artificial, however, as individual children may be simultaneously wasted and stunted [4] and each condition increases the subsequent risk of the other developing [5]. However, this review maintains this terminology, simply because this is how data have been reported to date.

To understand the physical consequences of undernutrition more fully, the simplest model of body composition divides mass into two components: fat-free mass (FFM) and fat mass (FM) [6]. Each of these components is of interest, as there is limited evidence that each is associated with the likelihood of survival in early life. First, when insufficient dietary protein or amino acids are available, muscle mass may provide critical proteins for immune function. Simple markers of depleted muscle mass have been associated with higher mortality risk $[7,8]$. Potential effects of undernutrition on non-muscle components of FFM have received very little attention. It is possible that organs are generically protected at the expense of muscle; however, reductions in thymus size associated with undernutrition have been linked with reduced immune competence [9]. Second, FM provides metabolic precursors and energy for immune function, which has high metabolic costs [10]. Moreover, FM secretes leptin; a 'gateway' hormone for immune function [11]. Two studies of children with severe-acute undernutrition have shown that mortality can be predicted by low levels of leptin [12, 13].

In recent decades, researchers have increasingly measured body composition in undernourished children. As increasing numbers of children survive undernutrition in the short-term, new questions are emerging regarding the long-term consequences and effects of treatment [14-16]. The aim of this non-systematic review is, first, to briefly review the body composition analysis methods that are appropriate for use in undernourished children and then to summarise published data on this topic. I will consider how body composition is associated with undernutrition at baseline, how it changes during treatment and the longerterm effects.

\section{Methodological issues}

Although simple anthropometry (body mass index, BMI) is often used as a proxy for body composition, its associations with fatness are generally weak [17]. This approach is also particularly unsuitable for assessing associations between stunting and body composition. When height is incorporated in measurements of both exposure (HAZ) and outcome (BMI), any error in height measurement generates an autocorrelation between short stature and high BMI $[18,19]$. Thus, early reports linking stunting with an elevated risk of overweight categorised by BMI [20] should be treated with caution. Direct measurement of adiposity is recommended.

There is no gold standard for body composition assessment - other than cadaver dissection. All in vivo techniques are necessarily imperfect and require assumptions to convert from raw measurements to final body composition values [6]. It is challenging to obtain data from young children - more so if they are unwell. Nonetheless, objective methods have recently been applied to undernourished children, including deuterium dilution $\left(\mathrm{D}_{2} \mathrm{O}\right)[14,15]$, dual-energy X-ray absorptiometry (DXA) [21, 22] or bioelectrical impedance analysis (BIA) $[14,16]$. In specialised research centres in high-income countries, it is also possible to obtain accurate information using magnetic resonance imaging (MRI) [23] or multi-component models (MCM) that rely on fewer theoretical assumptions [24].

A related challenge is that, until recently, minimal reference data were available for healthy individuals [25], other than the estimated average tissue masses of the 'reference child' of Fomon et al. [26]. Several publications from highincome countries have described the full range of healthy body composition parameters - in some cases for younger age groups, such as birth to 2 years in the US (MCM) [27] and 6 weeks to 5 years in the UK $\left(\mathrm{D}_{2} \mathrm{O}\right)$ [28]. However, these have limited relevance to low- and middle-income country (LMIC) settings, where sustained environmental stresses (e.g., constrained food supply, infectious diseases) affect growth of the entire population to some degree. Reference data from birth to 6 months of age were published for Ethiopia (using air displacement plethysmography) [29] and for children aged $\geq 5$ years in India [30,31]. In the absence of similar data from other LMICs, measuring healthy controls from the same setting remains essential for interpreting data [16], although these controls may also have experienced undernutrition earlier in life.

Body composition is closely associated with body size. When researching the immediate or long-term consequences of undernutrition, it is important to disentangle size variability from that of body composition [25]. Calculating percentage body fat is a flawed approach, as high values might reflect either high FM or low FFM [32]. A more appropriate approach is to adjust tissue masses for height, dividing each of FFM and FM by height-squared. The resulting fat-free mass index (FFMI) and fat mass index (FMI) are both expressed in the same $\mathrm{kg} / \mathrm{m}^{2}$ units as BMI [33]. Reference data for these outcomes are emerging [28] and height-adjusted outcomes are increasingly reported in child undernutrition research $[15,34,35]$.

Methodological issues remain in need of further research. First, for example, if undernutrition coexists with oedema, many of the assumptions used to convert raw data into final body composition values are violated [36]. The data reported below are currently the best available, 
but may still suffer from limitations, depending on the severity of undernutrition. Second, most data relate only to FFM and FM, and this limits our understanding of the exact nature of FFM depletion and its functional consequences.

\section{Body composition following severe-acute undernutrition}

The major weight loss that characterises wasted children may impact both fat and fat-free tissue. However, the effect of hydration perturbations on measurement techniques makes it difficult to obtain accurate data. In a UK study using MCM, adolescents with the eating disorder anorexia nervosa had $1.4 \mathrm{z}$-scores lower FM than controls and $1.1 \mathrm{z}$-scores lower FFM, along with deficits in bone and protein mass [24]. Adjusting for height, regional analyses showed substantial loss of FM in both limbs and trunk, whereas for FFM the main loss was in the limbs only. Other studies of adult women with anorexia nervosa using magnetic resonance imaging have shown that intra-abdominal fat is relatively preserved during weight loss and increases most during refeeding $[37,38]$. These studies clearly show that severe weight loss affects all body components, but the results have limited significance for younger LMIC populations in which undernutrition is often associated with infection.

Given the high mortality risk associated with severe-acute undernutrition in LMICs, body composition measurements have historically been rare, but the emerging data show some patterns. Table 1 summarises the details of studies considered below, to illustrate how this field has progressed.
A recent study of children with severe-acute undernutrition in Ethiopia used a version of BIA known as bioelectrical impedance vector analysis (BIVA) to differentiate between low cell mass and dehydration/ oedema. Consistent with simple clinical assessments, BIVA measurements successfully differentiated between dehydrated and oedematous children with severe-acute undernutrition [39]. Although BIVA does not give absolute values, both oedematous and non-oedematous children with severe-acute undernutrition had markers of low cell mass, broadly equivalent to reduced FFM, relative to healthy control children from the same setting. Oedematous children lost excess fluid during treatment, while non-oedematous children appeared to gain small amounts of fat-free tissue [39]. This methodology holds promise for incorporating assessment of hydration status in future studies. Moreover, BIVA parameters correlate with biochemical markers of nutritional status [43].

A study from Cambodia analysed data from a randomised trial investigating the potential of four ready-touse therapeutic foods (RUTFs) to prevent undernutrition [44]. In this study, body composition was assessed using $\mathrm{D}_{2} \mathrm{O}$ at 6 and 15 months of age [35]. In observational analyses of these data, FFM declined strongly in proportion with the degree of wasting at both time-points, whereas declines in fat mass were more modest (Fig. 1). These contrasts broadly persisted following adjustment for height (i.e. analysing FFMI and FMI). The FFM deficits of wasted children increased with age, whereas FM

Table 1 Studies associating severe-acute undernutrition with body composition in children from low and middle-income countries

\begin{tabular}{|c|c|c|c|c|c|}
\hline $\begin{array}{l}\text { Country } \\
\text { [Reference] }\end{array}$ & Location & Categories of undernutrition & Sample size & Age & $\mathrm{BC}$ techniques \\
\hline Ethiopia [39] & Jimma (urban area) & $\begin{array}{l}\text { Oedematous severe-acute } \\
\text { undernutrition } \\
\text { Non-oedematous severe-acute } \\
\text { undernutrition } \\
\text { Community controls }\end{array}$ & $\begin{array}{l}214 \\
136 \\
120\end{array}$ & $\begin{array}{l}\mathrm{L} \text { (during treatment), } \\
0-14 \text { years at baseline }\end{array}$ & BIVA \\
\hline DR Congo [14] & $\begin{array}{l}\text { Kabare administrative zone, } \\
\text { South Kivu province }\end{array}$ & $\begin{array}{l}\text { MUAC }<115 \mathrm{~mm} \text { or bilateral } \\
\text { pitting } \\
\text { oedema }\end{array}$ & 47 controls, 55 cases & $\begin{array}{l}\mathrm{L} \text { (during treatment), } \\
15 \text { months (range } \\
6-23 \text { months) at baseline }\end{array}$ & $\mathrm{BIVA}, \mathrm{D}_{2} \mathrm{O}$ \\
\hline Malawi [16] & Blantyre & $\begin{array}{l}\text { Severe-acute undernutrition } \\
\text { survivors } \\
\text { Sibling controls } \\
\text { Community controls }\end{array}$ & $\begin{array}{l}352 \\
184 \\
217\end{array}$ & $\begin{array}{l}\mathrm{L} \text {, median } 9.3 \text { years } \\
\text { at follow-up } \\
(\mathrm{IQR} 8-10)\end{array}$ & $\begin{array}{l}\text { BIVA, } \\
\text { Grip strength }\end{array}$ \\
\hline Cambodia [35] & $\begin{array}{l}\text { Rural municipalities in Prey } \\
\text { Veng province, southeast } \\
\text { of Phnom Penh }\end{array}$ & $\begin{array}{l}\text { WHZ }<-2 \\
W H Z-2 \text { to }-1 \\
W H Z-1 \text { to } 0 \\
W H Z>0\end{array}$ & $\begin{array}{l}34 \\
119 \\
169 \\
90\end{array}$ & $\begin{array}{l}L \text {, measurements at } \\
6 \text { and } 15 \text { months }\end{array}$ & $\mathrm{D}_{2} \mathrm{O}$ \\
\hline Turkey [40] & Diyarbakir & $\begin{array}{l}\text { 'Severe undernutrition' } \\
\text { assessed by WAZ }\end{array}$ & $\begin{array}{l}74 \text { cases } \\
47 \text { controls }\end{array}$ & $6-52$ months & Ultra-sonography \\
\hline Egypt [41] & Cairo & WAZ $<60 \%$ & $\begin{array}{l}30 \text { cases } \\
10 \text { controls }\end{array}$ & $6-36$ months & Echo-cardiography \\
\hline Thailand [42] & Chiang Mai & $W H Z<70 \%$ & 11 & 10-43 months & Chest radiograph \\
\hline
\end{tabular}

Abbreviations: $B C$ body composition, $B I V A$ bioelectrical impedance vector analysis, $D_{2} O$ deuterium dilution, $D R$ Democratic Republic, $I Q R$ interquartile range, $L$ longitudinal study, MUAC mid-upper arm circumference, WAZ weight-for-age $z$-score, WHZ weight-for-height z-score 
(a)

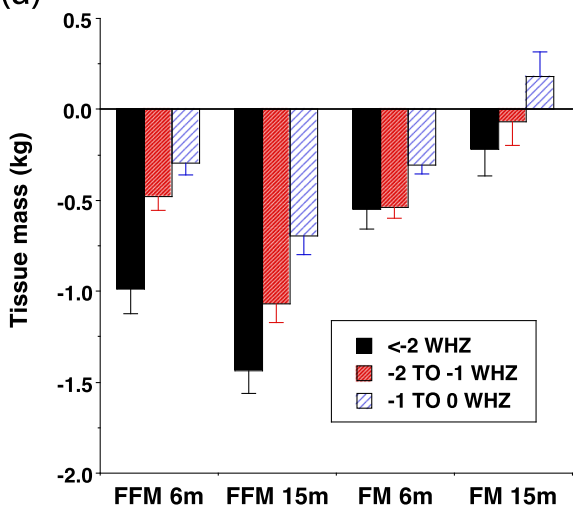

(b)

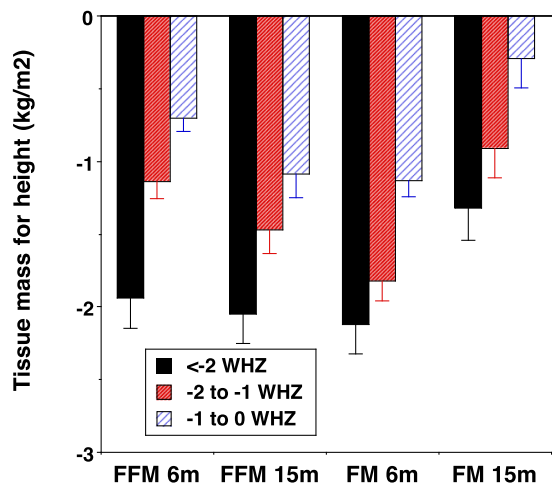

Fig. 1 Association between body composition outcomes and the severity of wasting, categorised by weight-for-height z-scores. Data shown are from a longitudinal study of child undernutrition in rural Cambodia [35]. Effects for the three categories of low weight-for-height z-score (WHZ) are expressed relative to a reference group with $W H Z>0$. a Absolute fat-free mass (FFM) and fat mass (FM). $\mathbf{b}$ Height adjusted fat-free mass index (FFMI) and fat mass index (FMI). Error bars are standard error of the mean

deficits reduced [35], indicating a relative preservation of FM over FFM over time in severe undernutrition.

A long-term follow-up of survivors of severe-acute undernutrition in Malawi showed that, compared to community and sibling controls, the children had recovered some of their deficit in height, but nevertheless remained shorter in height with shorter leg lengths. They had smaller calf circumference and MUAC. BIVA revealed markers of lower FFM and they also had lower grip strength. They had similar waist girth, but lower hip girth, suggesting a more central distribution of body fat [16]. Although no direct body composition data were collected in this study, the available data indicate that the severe-acute undernutrition survivors had lower levels and functional capacities of FFM, alongside depleted peripheral but preserved central adiposity.

Very few studies have assessed the size of specific organs, but studies from Egypt and Thailand found that infants and young children with severe-acute undernutrition, whether oedematous or non-oedematous, had small heart volume and reduced cardiac muscle [41, 42]. A similar study of young children with marasmus from Turkey reported lower kidney volumes [40]. A systematic review of the effects of undernutrition on immune function found consistent evidence of severe thymus atrophy [45].

Overall, severe wasting clearly affects both fat and fat-free tissues and although levels of fat may subsequently recover, levels of FFM may remain low in the longer-term. A subtler finding is the relative preservation of central compared to peripheral fat depots. However, there are as yet minimal data on individual organs and the long-term consequences of severeacute undernutrition for body composition remain poorly understood.
Body composition associated with chronic undernutrition A substantially greater proportion of the world's children are underweight and/or stunted than those that are severely wasted [1], and they have participated in a larger number of studies, some of them longitudinal. Table 2 summarises the locations, sample sizes and measurement techniques of the relevant studies reviewed below.

In the study from Cambodia discussed above, FFM declined strongly in proportion with the degree of linear growth retardation at both 6 and 15 months. However, these trends effectively disappeared on adjustment for height (i.e. analysing FFMI and FMI) (Fig. 2). Crude associations between FM and the magnitude of growth faltering were weaker; again they disappeared after adjusting for height [35]. In this study, therefore, tissue accretion was proportional to linear growth, with FFM most affected in absolute terms.

A study in Jamaica followed up children who had been either stunted or not at 2 years of age. Subcutaneous skinfold data was collected from participants at 17 years of age, as well as BMI data throughout adolescence. At 17 years old, previously stunted children remained shorter, had a lower BMI and showed no signs of greater central fat deposition. Instead, the stunted children showed faster linear growth between the ages of 3 and 11 years and had therefore reduced some of their height deficit by adolescence [47].

Similar findings were obtained in a follow-up of children in Nepal. Comparing children who had or had not been stunted at 2 years of age, those who had been stunted maintained a shorter height and had a lower BMI at 8 years of age [48]. FFM and kidney dimensions were reduced and these differences remained evident albeit with smaller magnitude - after adjusting for their shorter height (i.e. analysing FFMI and FMI). The 
Table 2 Studies associating chronic undernutrition with body composition in children from low and middle-income countries

\begin{tabular}{|c|c|c|c|c|c|}
\hline $\begin{array}{l}\text { Country } \\
\text { [Reference] }\end{array}$ & Location & $\begin{array}{l}\text { Categories of } \\
\text { undernutrition }\end{array}$ & Sample size & Age & $\mathrm{BC}$ techniques \\
\hline Brazil [22] & Slums of Sao Paulo & $\begin{array}{l}\mathrm{HAZ}<-2 \\
\mathrm{HAZ}>-2\end{array}$ & $\begin{array}{l}13 \\
29\end{array}$ & CS, $11-15$ years & DXA \\
\hline Peru [46] & $\begin{array}{l}\text { Lowland (Pampas de San Juan de } \\
\text { Miraflores, Lima), and highland (rural } \\
\text { communities of Santillana and Vinchos } \\
\text { Districts of Ayacucho Region) }\end{array}$ & $\begin{array}{l}\text { Height analysed on } \\
\text { continuous basis }\end{array}$ & $\begin{array}{l}\text { Lowland } \\
201 \\
\text { Highland } \\
160\end{array}$ & $\mathrm{CS}, 3-8.5$ years & Waist girth \\
\hline Jamaica [47] & Poor neighbourhoods of Kingston & $\begin{array}{l}\mathrm{HAZ}<-2 \\
\mathrm{HAZ}>-2\end{array}$ & $\begin{array}{l}103 \\
64\end{array}$ & $\begin{array}{l}\text { L, stunting assessed at }<2 \text { years; } \\
\text { follow-up at } 7,11 \text { and } 17 \text { years }\end{array}$ & Skinfolds, girths \\
\hline $\begin{array}{l}\text { Cambodia } \\
\text { [35] }\end{array}$ & $\begin{array}{l}\text { Rural municipalities in Prey Veng } \\
\text { province, southeast of Phnom Penh }\end{array}$ & $\begin{array}{l}\mathrm{HAZ}<-2 \\
\mathrm{HAZ}-2 \text { to }-1 \\
\mathrm{HAZ}-1 \text { to } 0 \\
\mathrm{HAZ}>0\end{array}$ & $\begin{array}{l}34 \\
119 \\
169 \\
90\end{array}$ & $\begin{array}{l}\mathrm{L} \text {, measurements at } 6 \text { and } 15 \\
\text { months }\end{array}$ & $\mathrm{D}_{2} \mathrm{O}$ \\
\hline Nepal [48] & Janakpur, Terai District & $\begin{array}{l}H A Z<-2 \\
H A Z>-2\end{array}$ & $\begin{array}{l}309 \\
494\end{array}$ & $\begin{array}{l}\text { L, stunting assessed at } 2 \text { years; } \\
\text { follow-up at } 8 \text { years }\end{array}$ & $\begin{array}{l}\text { BIA, skinfolds, girths, } \\
\text { kidney dimensions }\end{array}$ \\
\hline India [49] & $\begin{array}{l}\text { Areas of low socioeconomic status } \\
\text { in Mumbai city, Maharashtra }\end{array}$ & $\begin{array}{l}\mathrm{HAZ}<-2 \\
\mathrm{HAZ}>-2\end{array}$ & $\begin{array}{l}330 \\
330\end{array}$ & CS, 2-4 years & Skinfolds, girths \\
\hline Senegal [50] & Niakhar rural district & $\begin{array}{l}\mathrm{HAZ}<-2 \\
\mathrm{HAZ}>-2\end{array}$ & $\begin{array}{l}81 \\
286\end{array}$ & $\begin{array}{l}\text { L, stunting assessed at } 6-18 \text { months; } \\
\text { follow-up at } 11 \text { and } 15 \text { years }\end{array}$ & Skinfolds, girths \\
\hline $\begin{array}{l}\text { South Africa } \\
\text { [51] }\end{array}$ & $\begin{array}{l}\text { Township setting outside } \\
\text { Potchefstroom, North-West Province }\end{array}$ & $\begin{array}{l}\mathrm{HAZ}<-2 \\
\mathrm{HAZ}>-2\end{array}$ & $\begin{array}{l}32 \\
146\end{array}$ & CS, 13-18 year range & $\begin{array}{l}\text { Skinfolds, girths, } \\
\text { densitometry }\end{array}$ \\
\hline $\begin{array}{l}\text { South Africa } \\
\text { [21] }\end{array}$ & $\begin{array}{l}\text { Birth-to-Twenty cohort, Soweto, } \\
\text { Johannesburg }\end{array}$ & $\mathrm{HAZ}<-2, \mathrm{HAZ}>-2$ & Total 140 & $\begin{array}{l}L, \text { Stunting assessed at } 1 \text { and } 2 \\
\text { years; follow-up at } 8 \text { years }\end{array}$ & DXA \\
\hline
\end{tabular}

Abbreviations: $B C$ body composition, $B I A$ bioelectrical impedance analysis, $C S$ cross-sectional study, $D_{2} O$ deuterium dilution, $D X A$ dual-energy $X$-ray absorptiometry, $H A Z$ height-for-age $z$-score, $L$ longitudinal study. The south Africa study measured stunting at two time points in 140 children, but did not quantify the numbers stunted at either time point

percentage deficit in FM at 8 years of age $(\sim 35 \%)$ was substantially greater than that in FFM $(\sim 15 \%)$. Both central and limb skinfold thicknesses were reduced, as were both waist and hip girths. There was no evidence of early-life stunting being associated with a more central fat deposition in this cohort.

However, other studies show contrasting patterns. Early studies of children from Brazilian shanty towns found that stunted adolescents, especially girls, had higher weightfor-height than healthy controls [52], suggesting an association between early linear growth faltering and later overweight. Subsequent studies using DXA found that stunted children gained less FFM than non-stunted children over a 3-year period, whereas boys, but not girls, gained more FM than controls [22]. Mechanistic studies in the same population found that stunted children had lower rates of fat oxidation than non-stunted children, which might predispose them to fat accretion [53]. Reduced fat oxidation in stunted children was also observed in children from North Korea [54]. However, a study in Cameroon did not replicate this association [55].

A longitudinal study of Senegalese girls found that those stunted at 6-18 months of age also had lower subcutaneous skinfold thickness, arm girth and BMI than their non-stunted peers at that time [50]. By the age of 15 years, the stunted girls had not caught up in height, but had caught up in body mass and no longer showed differences in arm girth or the sum of six skinfold thicknesses. However, there were subtle differences in fat distribution, with the stunted girls showing a slightly more central fat distribution in adolescence, as indicated by higher biceps and subscapular skinfolds.

A cross-sectional comparison of children living at high and low altitude in Peru (encompassing a range of height variation) found that the association between indices of adiposity and height varied markedly between the two settings [46]. At low altitude, height was positively associated with waist girth, suggesting that faster growing children were investing in both linear growth and adipose tissue deposition. However, at high altitude, height was inversely associated with waist girth, suggesting a trade-off between linear growth and fat deposition, with the shortest children investing relatively more in FM.

A cross-sectional study in India reported that stunted children aged 2-4 years had higher levels of total and central body fat than non-stunted counterparts [49]. In both sexes, stunted children were $\sim 10 \mathrm{~cm}$ shorter than the non-stunted children. However, the 'elevated body fat' described by these authors in stunted children was not apparent in absolute terms and only emerged after adjusting for birthweight and change in weight z-score between birth and follow-up. Specifically, the authors' statistical modelling tells us that if both stunted and non-stunted children had gained a similar amount of 

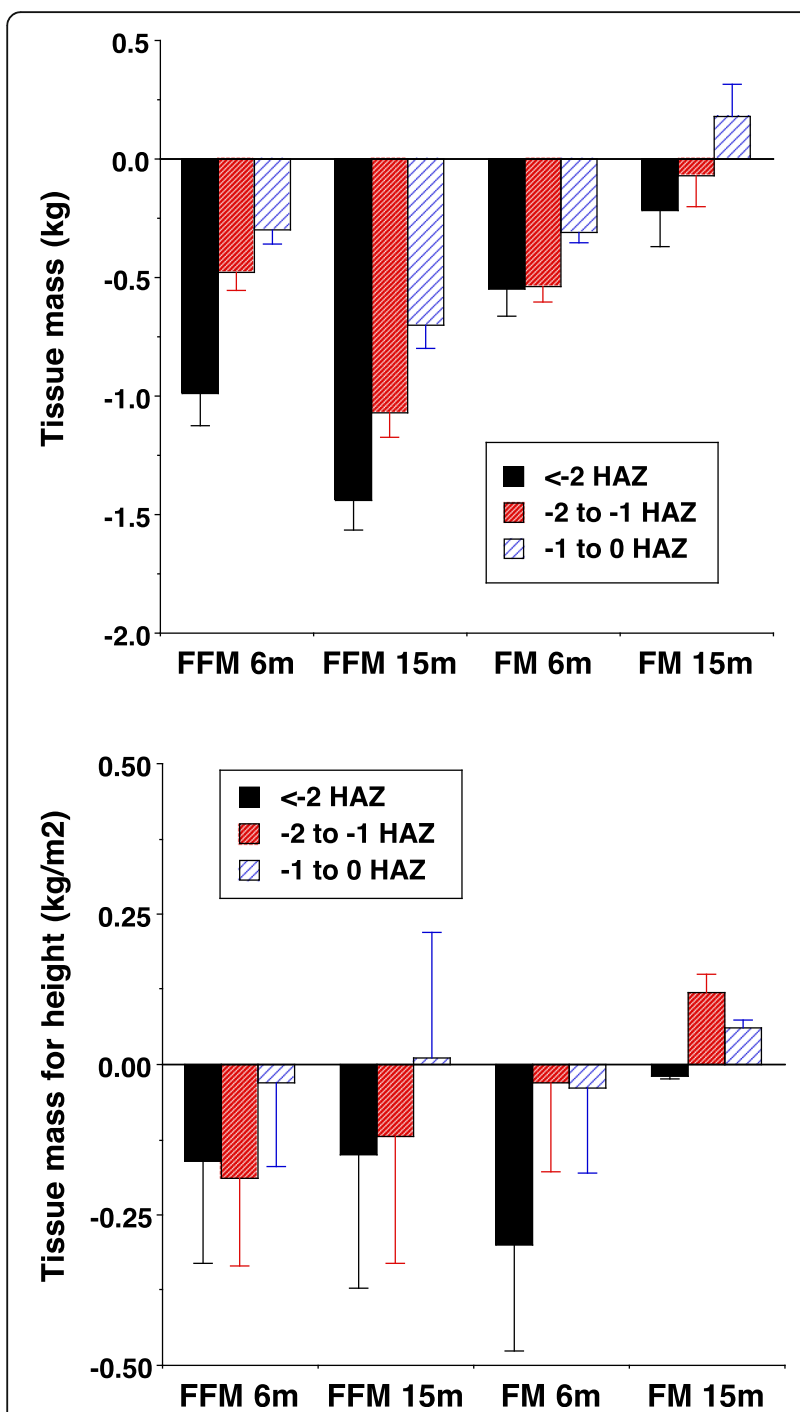

Fig. 2 Association between body composition outcomes and the severity of stunting, categorised by height-for-age z-scores. Data shown are from a longitudinal study of child undernutrition in rural Cambodia [35]. Effects for the three categories of low height-for-age z-score (HAZ) are expressed relative to a reference group with HAZ $>0$. a Absolute fat-free mass (FFM) and fat mass (FM). b Height adjusted fat-free mass index (FFMI) and fat mass index (FMI). Error bars are standard error of the mean

weight since birth, then it would be predicted that the stunted children would have greater adiposity. However, the stunted children had substantially lower postnatal weight gain than the non-stunted children. The shorter height and lower weight of the stunted children clearly indicates a substantial deficit in FFM. The purported increments in percentage fat and waist-for-height can be considered artefacts of this deficit, introduced by the statistical adjustments.

Similar concerns relate to a study of South African adolescents. Stunting was not associated with elevated skinfolds or waist girth. Although not significantly different, percentage fat was slightly higher among the stunted group and these individuals had a higher waistto-hip ratio [51]. However, in recalculating the data, I revealed a substantial deficit in FFM in boys and a smaller effect in girls. Similarly, the higher waist-to-hip ratio in stunted adolescents can be attributed to low hip girth rather than high waist girth. This study did not, therefore, directly link stunting to elevated total or central adiposity. In a different cohort from Soweto, near Johannesburg, where body composition at 10 years of age was measured by DXA, stunting at 1 year of age was associated with lower FM and FFM at 10 years. At 2 years of age, stunting was associated only with lower FFM [21].

Overall, studies of stunted children have relatively consistently showed long-term deficits in FFM. In some cases, these deficits are proportional to the shorter height and in other cases the deficit persists even after adjusting for height. Whether stunting is causally associated with later adiposity remains less clear - an issue revisited below.

\section{Effects of treatment}

A study in the Democratic Republic of Congo randomised young children with severe-acute undernutrition to different doses of RUTF. At the time of discharge, body composition was assessed using BIA and $\mathrm{D}_{2} \mathrm{O}$, allowing the assessment of differences between patients and healthy controls and between the two trial groups. Compared with controls, the undernourished children still had lower FFM; however, the difference in FM was smaller and only significant in one of the two trial groups [14]. There were no significant differences in any body composition outcome between the two trial groups.

Regarding specific tissues and organs, an earlier study from Jamaica found that after clinical recovery from severeacute undernutrition, infants' muscle fibres increased in cross-sectional area, but remained small in size compared with controls. This suggests that complete muscle recovery is either slow or impossible [56]. However, the study of infants and young children with severe-acute undernutrition in Egypt reported a significant improvement in cardiac muscle following nutritional rehabilitation [41].

The reports of a potential association between stunting and fat accretion described above prompted concern that nutritional supplementation programmes, which deliberately seek to increase energy intake, might inadvertently elevate fatness in short children rather than promote growth in height and FFM. For example, earlier studies of nutritional treatment for severe-acute undernutrition reported high rates of fat accretion [57-59], which may be partly explained by diets lacking adequate micronutrients to support FFM accretion. Likewise, during recovery from long-term chronic undernutrition, 
adult participants in the 1950s Minnesota Starvation Study initially accumulated FM much faster than FFM, though baseline FFM was eventually recovered [60].

Of relevance here, the $\mathrm{D}_{2} \mathrm{O}$ method was recently used in a longitudinal trial in Burkina Faso to test the effects of 12 RUTFs in moderately undernourished young children [15]. This study had no control group, making it difficult to evaluate the deficits in FFM and FM prior to treatment, but - relative to UK reference data [28] these children had major deficits in both tissues at baseline. Over 12 weeks, $93.5 \%$ of weight gain was accounted for by FFM. At the end of the study, FFM had increased by $\sim 1 \mathrm{z}$-score and was similar to the UK reference median, whereas FM remained well below the UK median. Using height-adjusted outcomes, FFMI also increased by $0.80 \mathrm{~kg} / \mathrm{m}^{2}$, whereas FMI showed a non-significant decline of $0.05 \mathrm{~kg} / \mathrm{m}^{2}$. Stratifying children by height at baseline, there was no evidence that short children gained greater levels of FM during treatment [34].

In the similar trial from Cambodia, nutritional supplementation was provided for children with moderateacute undernutrition for a longer period (6-15 months). In this trial, the average gain in FFM was $2.0 \mathrm{~kg}$, while fat mass decreased, on average, by $0.2 \mathrm{~kg}$, with no difference between the four trial groups receiving different RUTF formulations [44]. These two studies are consistent with other recent studies of treatment for severeacute undernutrition [14, 61], in which, again, adiposity was not found to be elevated following RUTF treatment.

\section{Conclusions}

Although further research is urgently needed, available data from LMICs on the association between undernutrition and body composition has revealed some relatively clear findings, as well as some areas of inconsistency.

First, all forms of undernutrition appear to adversely impact FFM, either in proportion to linear growth retardation or even more severely. These deficits often persist in the long-term and are associated with functional deficits, such as lower grip strength. However, a major gap in the literature relates to the effects of undernutrition on specific organs and muscle.

Second, undernutrition also reduces adiposity in the short-term. This is unsurprising, given that a key function of fat is to provide energy and molecular substrates for immune function when nutritional intake is depleted [10]. There are some indications that fat may be relatively preserved over time, suggesting that the body may sacrifice FFM to maintain crucial energy reserves for further 'fire-fighting'. However, it is less clear whether children whose early growth was slowed are inherently at risk of gaining excess adiposity. Many studies fail to support this hypothesis and, while others might appear to support it, they suffer from statistical problems. Of those studies that did find a link between stunting and later elevated adiposity, the underlying mechanism remains unclear. Further research is needed to determine whether stunting alters metabolism or appetite in favour of fat accretion, or whether poor diets (energy dense but deficient in micronutrients) contribute to both stunting and overweight (Fig. 3). It is plausible that populations from different geographical regions have evolved contrasting biological responses to undernutrition; however, this hypothesis has yet to be explored.

Third, associations between undernutrition and body composition may contribute in the long-term to elevated non-communicable disease (NCD) risk. Low FFM indicates a low 'metabolic capacity' for homeostasis and thus a reduced ability to tolerate the 'metabolic load' associated with high levels of adiposity (regardless of how that adiposity accumulates) in later life [62, 63]. For example, short adult stature is a well-recognised risk factor for NCDs such as cardiovascular disease and diabetes [64, 65]. However, until adiposity becomes elevated, survivors of undernutrition may not present with overt NCD risk, as indicated by the lack of difference in risk markers compared to controls in the follow-up study in Malawi [16].

Finally, although methodological challenges remain, there is a steadily growing choice of methods appropriate for research on this topic, as well as more comprehensive reference data. As the agenda in child undernutrition moves beyond simply helping children to 'survive' in the short-term, to helping them 'thrive' in the long-term, body composition research will become increasingly important.

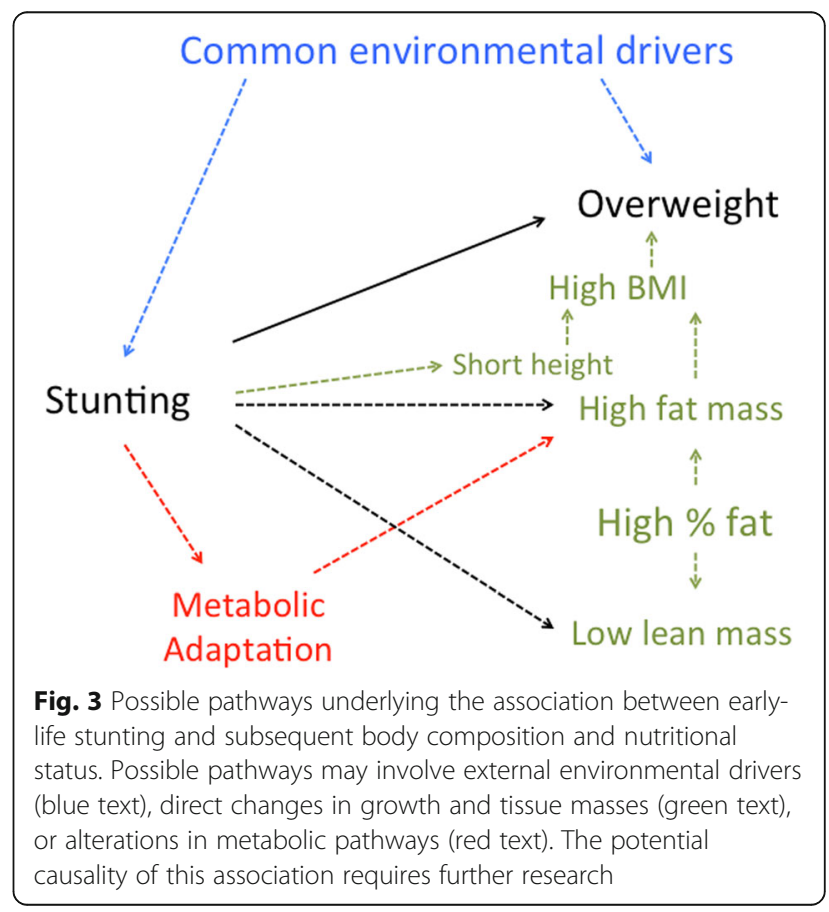




\section{Abbreviations}

BIA: Bioelectrical impedance analysis; BIVA: Bioelectrical impedance vector analysis; BMI: Body mass index; $\mathrm{D}_{2} \mathrm{O}$ : Deuterium dilution; DXA: Dual-energy $\mathrm{X}$ ray absorptiometry; FFM: Fat-free mass; FFMI: Fat-free mass index; FM: Fat mass; FMI: Fat mass index; HAZ: Height-for-age z-score; LMIC: Low- and middle-income countries; MCM: Multi-component model; MUAC: Mid-upper arm circumference; NCD: Non-communicable disease; RUTF: Ready-to-use therapeutic food; WHZ: Weight-for-height z-score

\section{Acknowledgements}

Not applicable.

\section{Authors' contributions}

JW designed and wrote the manuscript in response to an invitation from the BMC Medicine editors. The author read and approved the final manuscript.

\section{Funding}

No funding was given in association with this manuscript.

\section{Availability of data and materials}

Not applicable.

\section{Ethics approval}

Not applicable.

\section{Consent for publication}

Not applicable.

\section{Competing interests}

The author has received two bioelectrical impedance analysis instruments gratis from Bodystat, one of which was used in some of the studies described above $[39,43]$. The author has no other conflicts of interest to declare.

Received: 12 August 2019 Accepted: 8 November 2019 Published online: 25 November 2019

\section{References}

1. Black RE, Victora CG, Walker SP, Bhutta ZA, Christian P, de Onis M, et al. Maternal and child undernutrition and overweight in low-income and middle-income countries. Lancet. 2013;382:427-51.

2. Waterlow JC. Note on the assessment and classification of protein-energy malnutrition in children. Lancet. 1973;2:87-9.

3. Development Initiatives. 2018 global nutrition report: shining a light to spur action on nutrition. Bristol: Development Initiatives Poverty Research Ltd; 2018. https://globalnutritionreport.org. Accessed 03 Oct 2019

4. Wells JC, Briend A, Boyd EM, Berkely JA, Hall A, Isanaka S, et al. Beyond wasted and stunted - a major shift to fight child undernutrition. Lancet Child Adolesc Health. 2019;3:831-4

5. Schoenbuchner SM, Dolan C, Mwangome M, Hall A, Richard SA, Wells JC, et al. The relationship between wasting and stunting: a retrospective cohort analysis of longitudinal data in Gambian children from 1976 to 2016. Am J Clin Nutr. 2019;110:498-507.

6. Wells JC, Fewtrell MS. Measuring body composition. Arch Dis Child. 2006;91: 612-7.

7. Briend A, Garenne M, Maire B, Fontaine O, Dieng K. Nutritional status, age and survival: the muscle mass hypothesis. Eur J Clin Nutr. 1989:43:715-26.

8. Briend A, Khara T, Dolan C. Wasting and stunting - similarities and differences: policy and programmatic implications. Food Nutr Bull. 2015; 36(Suppl):S15-23.

9. Prentice AM. The thymus: a barometer of malnutrition. Br J Nutr. 1999;81: 345-7.

10. Wells JC. The evolutionary biology of human body fat: thrift and control. Cambridge: Cambridge University Press; 2010

11. Lord G. Role of leptin in immunology. Nutr Rev. 2002;60:S35-8.

12. Bartz S, Mody A, Hornik C, Bain J, Muehlbauer M, Kiyimba T, et al. Severe acute malnutrition in childhood: hormonal and metabolic status at presentation, response to treatment, and predictors of mortality. J Clin Endocrinol Metab. 2014;99:2128-37.
13. Njunge JM, Gwela A, Kibinge NK, Ngari M, Nyamako L, Nyatichi E, et al. Biomarkers of post-discharge mortality among children with complicated severe acute malnutrition. Sci Rep. 2019;9:5981.

14. Bahwere $P$, Balaluka B, Wells JC, Mbiribindi CN, Sadler K, Akomo P, et al. Cereals and pulse-based ready-to-use therapeutic food as an alternative to the standard milk- and peanut paste-based formulation for treating severe acute malnutrition: a noninferiority, individually randomized controlled efficacy clinical trial. Am J Clin Nutr. 2016;103:1145-61.

15. Fabiansen C, Yameogo CW, luel-Brockdorf AS, Cichon B, Rytter MJH, Kurpad $A$, et al. Effectiveness of food supplements in increasing fat-free tissue accretion in children with moderate acute malutrition: a randomised $2 \times 2 \times$ 3 factorial trial in Burkina Faso. PLoS Med. 2017;14:e1002387.

16. Lelijveld N, Seal A, Wells JC, Kirkby J, Opondo C, Chimwezi E, et al. Chronic disease outcomes after severe acute malnutrition in Malawian children (ChroSAM): a cohort study. Lancet Glob Health. 2016:4:e654-62.

17. Wells JC. A Hattori chart analysis of body mass index in infants and children Int J Obes Relat Metab Disord. 2000;24:325-9.

18. Haaga JG. Negative bias in estimates of the correlation between children's weight-for-height and height-for-age. Growth. 1986;50:147-54.

19. Timaeus IM. Stunting and obesity in childhood: a reassessment using longitudinal data from South Africa. Int J Epidemiol. 2012:41:764-72.

20. Popkin BM, Richards MK, Montiero CA. Stunting is associated with overweight in children of four nations that are undergoing the nutrition transition. J Nutr. 1996;126:3009-16.

21. Kagura J, Feeley AB, Micklesfield LK, Pettifor JM, Norris SA. Association between infant nutrition and anthropometry, and pre-pubertal body composition in urban south African children. J Dev Orig Health Dis. 2012;3:415-23.

22. Martins PA, Hoffman DJ, Fernandes MT, Nascimento CR, Roberts SB, Sesso R, et al. Stunted children gain less lean body mass and more fat mass than their non-stunted counterparts: a prospective study. Br J Nutr. 2004;92:819-25.

23. Mayer LE, Klein DA, Black E, Attia E, Shen W, Mao X, et al. Adipose tissue distribution after weight restoration and weight maintenance in women with anorexia nervosa. Am J Clin Nutr. 2009;90(5):1132-7.

24. Wells JC, Haroun D, Williams JE, Nicholls D, Darch T, Eaton S, et al. Body composition in young female eating-disorder patients with severe weight loss and controls: evidence from the four-component model and evaluation of DXA. Eur J Clin Nutr. 2015;69:1330-5.

25. Wells JC. Toward body composition reference data for infants, children, and adolescents. Adv Nutr. 2014;5:320S-9S.

26. Fomon SJ, Haschke F, Ziegler EE, Nelson SE. Body composition of reference children from birth to age 10 years. Am J Clin Nutr. 1982;35(Suppl):1169-75.

27. Butte NF, Hopkinson JM, Wong WW, Smith EO, Ellis KJ. Body composition during the first 2 years of life: an updated reference. Pediatr Res. 2000;47: 578-85.

28. Wells JCK, Davies PSW, Fewtrell MS, Cole TJ. Body composition reference charts for UK infants and children aged 6 weeks to 5 years based on measurement of total body water by isotope dilution. Eur J Clin Nutr. 2019. https://doi.org/10.1038/s41430-019-0409-x.

29. Andersen GS, Girma T, Wells JC, Kaestel P, Leventi M, Hother AL, et al. Body composition from birth to 6 mo of age in Ethiopian infants: reference data obtained by air-displacement plethysmography. Am J Clin Nutr. 2013;98: 885-94.

30. Chiplonkar S, Kajale N, Ekbote V, Mandlik R, Parthasarathy L, Borade A, et al. Reference centile curves for body fat percentage, fat-free mass, muscle mass and bone mass measured by bioelectrical impedance in Asian Indian children and adolescents. Indian Pediatr. 2017;54:1005-11.

31. Khadilkar A, Mandlik R, Chiplonkar S, Khadilkar V, Ekbote V, Patwardhan V. Reference centile curves for triceps skinfold thickness for Indian children aged 5 to 17 years and cut offs for predicting risk of childhood hypertension: a multi-centric study. Indian Pediatr. 2015;52:675-80.

32. Wells JC, Cole TJ. Adjustment of fat-free mass and fat mass for height in children aged 8 y. Int J Obes Relat Metab Disord. 2002;26:947-52.

33. Vanltallie TB, Yang MU, Heymsfield SB, Funk RC, Boileau RA. Heightnormalized indices of the body's fat-free mass and fat mass: potentially useful indicators of nutritional status. Am J Clin Nutr. 1990;52:953-9.

34. Fabiansen C, Phelan KPQ, Cichon B, Yameogo CW, luel-Brockdorff AS, Kurpad $A$, et al. Short malnourished children and fat accumulation with food supplementation. Pediatrics. 2018;142:e20180679.

35. Skau JKH, Grenov B, Chamnan C, Chea M, Wieringa FT, Dijkhuizen MA, et al. Stunting, wasting and breast-feeding as correlates of body composition in Cambodian children at 6 and 15 months of age. Br J Nutr. 2019;121:688-98. 
36. Girma T, Kaestel P, Workeneh N, Molgaard C, Eaton S, Andersen GS, et al. Bioimpedance index for measurement of total body water in severely malnourished children: assessing the effect of nutritional oedema. Clin Nutr. 2016:35:713-7.

37. Mayo-Smith W, Hayes CW, Biller BM, Klibanski A, Rosenthal H, Rosenthal DI. Body fat distribution measured with CT: correlations in healthy subjects, patients with anorexia nervosa, and patients with Cushing syndrome. Radiology. 1989;170:515-8.

38. Mayer L, Walsh BT, Pierson RN Jr, Heymsfield SB, Gallagher D, Wang J, et al. Body fat redistribution after weight gain in women with anorexia nervosa. Am J Clin Nutr. 2005:81:1286-91.

39. Girma Nigatu T. Bioimpedance in severely malnourished children: an emerging method for monitoring hydration of children with severe acute malnutrition. Copenhagen: Department of Nutrition, Exercise and Sports, Faculty of Science, University of Copenhagen; 2014. pp. 1-107.

40. Ece A, Gozu A, Bukte Y, Tutanc M, Kocamaz H. The effect of malnutrition on kidney size in children. Pediatr Nephrol. 2007;22:857-63.

41. El-Sayed HL, Nassar MF, Habib NM, Elmasry OA, Gomaa SM. Structural and functional affection of the heart in protein energy malnutrition patients on admission and after nutritional recovery. Eur J Clin Nutr. 2006:60:502-10

42. Phornphatkul C, Pongprot $Y$, Suskind R, George V, Fuchs G. Cardiac function in malnourished children. Clin Pediatr (Phila). 1994:33:147-54.

43. Girma T, Hother Nielsen AL, Kaestel P, Abdissa A, Michaelsen KF, Friis H, et al. Biochemical and anthropometric correlates of bio-electrical impedance parameters in severely malnourished children: a cross-sectional study. Clin Nutr. 2018;2018(37):701-5.

44. Skau JK, Touch B, Chhoun C, Chea M, Unni US, Makurat J, et al. Effects of animal source food and micronutrient fortification in complementary food products on body composition, iron status, and linear growth: a randomized trial in Cambodia. Am J Clin Nutr. 2015; 101:742-51.

45. Rytter MJ, Kolte L, Briend A, Friis H, Christensen VB. The immune system in children with malnutrition - a systematic review. PLoS One. 2014;9:e105017.

46. Pomeroy E, Stock JT, Stanojevic S, Miranda JJ, Cole TJ, Wells JC. Stunting, adiposity, and the individual-level "dual burden" among urban lowland and rural highland peruvian children. Am J Hum Biol. 2014;26: 481-90.

47. Walker SP, Chang SM, Powell CA. The association between early childhood stunting and weight status in late adolescence. Int J Obes. 2007;31:347-52.

48. Wells JCK, Devakumar D, Manandhar DS, Saville N, Chaube SS, Costello $A$, et al. Associations of stunting at 2 years with body composition and blood pressure at 8 years of age: longitudinal cohort analysis from lowland Nepal. Eur J Clin Nutr. 2019;73:302-10.

49. Savanur MS, Ghugre PS. BMI, body fat and waist-to-height ratio of stunted v. non-stunted Indian children: a case-control study. Public Health Nutr. 2016;19:1389-96

50. Benefice E, Garnier D, Simondon KB, Malina RM. Relationship between stunting in infancy and growth and fat distribution during adolescence in Senegalese girls. Eur J Clin Nutr. 2001;55:50-8.

51. Kruger HS, Pretorius R, Schutte AE. Stunting, adiposity, and low-grade inflammation in African adolescents from a township high school. Nutrition. 2010;26:90-9.

52. Sawaya AL, Dallal G, Solymos G, de Sousa MH, Ventura ML, Roberts SB, et al. Obesity and malnutrition in a Shantytown population in the city of Sao Paulo, Brazil. Obes Res. 1995;3(Suppl 2):107s-15s.

53. Hoffman DJ, Sawaya AL, Verreschi I, Tucker KL, Roberts SB. Why are nutritionally stunted children at increased risk of obesity? Studies of metabolic rate and fat oxidation in shantytown children from Sao Paulo. Brazil Am J Clin Nutr. 2000;72:702-7

54. Lee SK, Nam SY, Hoffman DJ. Growth retardation at early life and metabolic adaptation among north Korean children. J Dev Orig Health Dis. 2015;6: 291-8.

55. Said-Mohamed R, Bernard JY, Ndzana AC, Pasquet P. Is overweight in stunted preschool children in Cameroon related to reductions in fat oxidation, resting energy expenditure and physical activity? PLoS One. 2012;7:e39007.

56. Hansen-Smith FM, Picou D, Golden MH. Growth of muscle fibres during recovery from severe malnutrition in Jamaican infants. Br J Nutr. 1979;41:275-82.

57. Brooke OG, Wheeler EF. High energy feeding in protein-energy malnutrition. Arch Dis Child. 1976;51:968-71.
58. Fjeld CR, Schoeller DA, Brown $\mathrm{KH}$. Body composition of children recovering from severe protein-energy malnutrition at two rates of catch-up growth. Am J Clin Nutr. 1989:50:1266-75.

59. Radhakrishna KV, Kulkarni B, Balakrishna N, Rajkumar H, Omkar C, Shatrugna $\checkmark$. Composition of weight gain during nutrition rehabilitation of severely under nourished children in a hospital based study from India. Asia Pac J Clin Nutr. 2010;19:8-13.

60. Dulloo AG, Jacquet J, Girardier L. Poststarvation hyperphagia and body fat overshooting in humans: a role for feedback signals from lean and fat tissues. Am J Clin Nutr. 1997;65:717-23.

61. Binns $P$, Myatt $M$. Does treatment of short or stunted children aged 659 months for severe acute malnutrition using ready to use therapeutic food make them overweight? Data from Malawi Arch Public Health. 2018;76:78.

62. Wells JCK. The capacity-load model of non-communicable disease risk: understanding the effects of child malnutrition, ethnicity and the social determinants of health. Eur J Clin Nutr. 2018;72:688-97.

63. Wells JC. The metabolic ghetto: an evolutionary perspective on nutrition, power relations and chronic disease. Cambridge: Cambridge University Press; 2016.

64. Paajanen TA, Oksala NK, Kuukasjarvi P, Karhunen PJ. Short stature is associated with coronary heart disease: a systematic review of the literature and a meta-analysis. Eur Heart J. 2010;31:1802-9.

65. Wells JC, Pomeroy E, Walimbe SR, Popkin BM, Yajnik CS. The elevated susceptibility to diabetes in India: an evolutionary perspective. Front Public Health. 2016:4:145.

\section{Publisher's Note}

Springer Nature remains neutral with regard to jurisdictional claims in published maps and institutional affiliations.

Ready to submit your research? Choose BMC and benefit from:

- fast, convenient online submission

- thorough peer review by experienced researchers in your field

- rapid publication on acceptance

- support for research data, including large and complex data types

- gold Open Access which fosters wider collaboration and increased citations

- maximum visibility for your research: over $100 \mathrm{M}$ website views per year

At $\mathrm{BMC}$, research is always in progress.

Learn more biomedcentral.com/submissions 